\title{
Journal of European Studies
}

http://jes.sagepub.com/

\section{Contesting consensus culture: The case of Dutch Gothic}

R.L. Buikema and E. Wesseling

Journal of European Studies 2011 41: 123

DOI: $10.1177 / 0047244111399709$

The online version of this article can be found at:

http://jes.sagepub.com/content/41/2/123

Additional services and information for Journal of European Studies can be found at:

Email Alerts: http://jes.sagepub.com/cgi/alerts

Subscriptions: http://jes.sagepub.com/subscriptions

Reprints: http://www.sagepub.com/journalsReprints.nav

Permissions: http://www.sagepub.com/journalsPermissions.nav

Citations: http://jes.sagepub.com/content/41/2/123.refs.html

>> Version of Record - May 19, 2011

What is This? 


\title{
Contesting consensus culture: The case of Dutch Gothic
}

\author{
R. L. Buikema
}

Utrecht University

\section{E. Wesseling}

Maastricht University

\begin{abstract}
Until recently the Gothic novel was considered to be a predominantly Anglo-Saxon phenomenon, but there are now several studies that have convincingly uncovered relevant European contributions to the development of this genre. We are adding to this project of Anglo-European comparisons by investigating the case of Dutch literature. Has there been a Gothic tradition to speak of in Dutch literature, and if so, how may it serve to mitigate the Anglo-centrism of Gothic studies? We observe that the Gothic only became a significant phenomenon in post-war Dutch literature, developing into a veritable trend from the 1980s onwards. The article offers an explanation for the initial absence of the Gothic novel and for its upsurge in late twentieth-century fiction. We argue that the trajectory of the Gothic in Dutch literature can be understood in the light of the peculiarities of the modernization of Dutch society, a process whose pace and phasing differs considerably from the modernization of Britain. These observations are substantiated with readings of primary works.
\end{abstract}

\section{Keywords}

emancipation, Dutch literature, Gothic novel, modernization, the Netherlands

The Gothic novel was considered to be a predominantly Anglo-Saxon phenomenon up until recently. Time and again, its genealogy was traced back to British founding fathers and mothers. Lately, this perspective has been effectively challenged by, among others, the contributors to Avril Horner's superb collection of essays, European Gothic (2002). They demonstrate quite convincingly that the history of the Gothic novel is better

\footnotetext{
Corresponding author:

E. Wesseling, Department of Literature and Art, Maastricht University, P.O. Box 616, 6200 MD Maastricht, The Netherlands

Email: lies.wesseling@maastrichtuniversity.nl
} 
understood as a process of 'spirited exchange' between European literatures on the one hand and English and American writing on the other. ${ }^{1}$ This mutual exchange materialized through translations, creative misreadings and so on. We would like to enquire into this Anglo-European literary relationship by focusing on Dutch literature. Has there been a Gothic tradition to speak of in Dutch literature, and if so, how can it serve to mitigate the Anglo-centrism of Gothic studies?

At first glance, the history of Dutch fiction seems to corroborate rather than correct this view of the supposed dominance of the English Gothic novel. Eighteenth- and nineteenth-century Dutch writers hardly ever tried their hand at this genre. Most of the Gothic novels that were published in the Netherlands were translations of English and German works, but for the occasional exception. ${ }^{2}$ This state of affairs changed after World War II. Seminal post-war authors such as Willem Frederik Hermans, Hella Haasse and Gerard Reve prepared the ground for a native brand of Gothic with the volume of short stories Paranoia (1953), and novels such as De verborgen bron (The Hidden Source, 1950), De vierde man (The Fourth Man, 1981) and Au pair (1989). In the wake of these literary giants, the genre finally caught on in twentieth-century Dutch literature, developing into a veritable trend from the 1980s onwards. Leading contemporary novelists such as Renate Dorrestein, Helga Ruebsamen, Frans Kellendonk, Thomas Rosenboom, Vonne van der Meer, Manon Uphoff and Herman Franke have all produced works in the Gothic vein. ${ }^{3}$ Strangely enough, the increasing significance of the Gothic novel to Dutch literature has not received much notice thus far.

\section{Modernization and nostalgia}

The Gothic novel, then, is a belated phenomenon in Dutch literature. Why? And how can we explain developments such as these? The days are long gone when it was acceptable to explain literary history as an epiphenomenon of social change. However, to approach literature as a self-contained system in which a new literary work can only be understood as a reaction to a previous work is equally reductive and outmoded. Moreover, any radicalization of literary autonomy is at odds with the best practices in the field of Gothic studies that analyse the Gothic novel as a form of 'cultural work' . The genre in question has been fruitfully interpreted as a strategy for broaching the major tensions and fears that accompany the pursuit of emancipation and progress through reason (Hogle, 2002). Although the generic repertoire of the Gothic novel has changed considerably over time, its cultural function has remained more or less constant. Ever since its beginnings in the eighteenth century, it has staged the tensions and conflicts generated by the often violent and abrupt onset of modernity. In order to fulfil this function, novelists have mobilized a whole gamut of themes, motifs and stylistic devices that evoke the emotions of horror and terror. Here one may think of tropes such as the secluded mansion that should offer its inhabitants protection from the outside world but in fact harbours major threats inside, the found manuscript that contains crucial clues but happens to be indecipherable, or stylistic play with the contrasts between light and dark, inside and outside, upstairs and downstairs, animate and inanimate, past and present.

The transformations of modernity tend to impose themselves in cataclysmic fashion as so many forms of revolutionary upheaval (the Agrarian Revolution, the Industrial 
Revolution, the French Revolution, etc.). The Gothic novel performs cultural work upon these disruptions by throwing doubt on the supposed pastness of the past. Although the revolutions of modernity suggest that the link between past and present may be severed with one violent stroke, in the Gothic novel bygones are never really bygones. The dead refuse to be properly dead, what should be inanimate appears to be animate, family homes are haunted by unspeakable crimes committed in the past, and sinister echoes manifest themselves where silence should reign supreme. The Gothic novel displays a fundamentally ambivalent attitude towards the blessings of progress. On the one hand, the genre seems to embrace modern values. By dwelling on the corruptions and perversions of the ancien régime, it seems to bid good riddance to the old order. On the other hand, the persistent lingering over institutions long gone expresses a nostalgic fascination with the pre-modern past. While investigating this ambivalence towards modernization and progress, we want to take the literariness of literature seriously as a medium-specific form of social commentary that offers a unique take on major historical changes. The genre of the Gothic novel provided late twentieth-century Dutch authors with a literary repertoire of themes, motifs, symbols and narrative devices for developing a highly salient perspective on post-war society. Let us explain.

\section{Dutch literary culture}

In order to explain the marginality of the Gothic novel within eighteenth- and nineteenthcentury Dutch literature, we would like to venture the hypothesis that there was no felt need for such a cultural form in Dutch culture in general, and Dutch literary culture in particular, at the time. If we compare the modernization of the Netherlands with comparable processes in Britain or France, we have to conclude that the phasing and pace of the first differed significantly from the second. In some respects, the Netherlands modernized much earlier, and in other respects much later, than Britain. Thus, the first modern European economy was created in the Dutch Republic during its so-called Golden Age (1580-1702). International trade was one of the Republic's most important sources of income, and urbanization progressed considerably around that time. In 1600 at least onethird of the population were living in the cities. Moreover, Dutch farmers had already moved way beyond self-sufficient agrarian production by catering to the thriving cities, which necessitated a rationalization of farming methods as early as the seventeenth century, long before the British Agrarian Revolution. However, other modern transformations such as industrialization, individualization and secularization occurred much later in the Netherlands. The central importance of the cities and of international trade implied that the landed gentry had already ceased to be a significant social force before the seventeenth century. The Netherlands were basically ruled by upper-middle-class families who had gathered their wealth through commerce rather than inheritance. The Dutch class system was much more homogeneous and inclusive than its French or British counterparts, with the middling classes successfully absorbing large segments of both lower and higher social strata. The Dutch middle class exerted itself to educate, civilize and assimilate the lower strata with almost evangelical zeal.

During the nineteenth century, the Netherlands fully participated in the revolutionary modernization of the means of transportation and communication (the introduction of the 
steam engine, the expansion of the railway network, the introduction of the telephone and the telegraph, etc.). Due to the ongoing struggle with the encroaching sea, the Netherlands have always been at the leading edge of civil engineering. Its contributions to nineteenth-century innovations in the fields of media and mobility perpetuated this tradition, in keeping with the proverb: 'God created the world, and the Dutch created the Netherlands' (Van der Woud, 2006). Naturally, these infrastructural developments expanded the 'life world' of Dutch citizens both materially and intellectually. Soon enough, however, this expansion was countered by the development of the 'pillarization' system towards the end of the nineteenth century. Protestants and Catholics increasingly organized their political, social and cultural lives along the lines of separate 'pillars': that is, vertical social strata that cut through class differences, another factor which decreased the significance of class in the Netherlands. Protestants founded Protestant political parties, schools, universities, sports clubs and broadcasting organizations. They were supposed to marry other Protestants, do their shopping in Protestant shops, send their children to Protestant schools, vote for a Protestant party, etc. Catholics and Socialists organized themselves in the same manner. These pillars were instrumental in promoting the emancipation of marginalized social groups. Eventually, a fourth pillar was raised, namely that of the Liberals, not so much because they were in favour of pillarization, but because they were forced into it by the simple fact that the rest of society organized itself in this way. The pillarization system reduced the modernizing, expanding life world to monolithic, closely policed, separate spheres. This form of cultural apartheid remained intact up to the 1960s.

The different pace and phasing of the modernization of the Netherlands also comes out in the norms, values and tastes of the literary societies that exerted a strong impact on the evaluation and production of Dutch literature in the eighteenth and nineteenth centuries (Singeling, 1991; De Vries, 2001). These societies were one of the means by which the educated middle classes sought to spread its utilitarian, bourgeois system of values. Literature was to serve the useful purpose of fostering the cognitive, moral and cultural elevation of mankind (or, to put it differently, the expansion of the middle class). The literary circles made literature subservient to their civilizing mission: that is, to their efforts to spread the light of learning and common decency over as many members of the Dutch population as they could possibly reach. Decency was basically identified with typically bourgeois values such as loving one's neighbour, devotion to a higher purpose than one's immediate self-interest, charity, thrift, diligence, loyalty, and so on. This intersection of social and literary interests did not exactly foster the rise of a native brand of Gothicism.

Initially, the literary societies were inclusive, in the sense that they wanted to civilize the whole of the Dutch nation. As such, they had no use for a fixation on the crimes of evil aristocrats that was typical of the eighteenth-century Gothic novel. At first, the nondenominational literary societies counted both Protestants and Catholics amongst their members, who were united in the common purpose of raising the cultural and moral level of the Dutch nation. The rabid anti-Catholicism of the early Gothic novel, which exposed the perversions of depraved clergymen with great relish, must have been offensive to the literary societies who did not have anything to gain from alienating their Catholic members. Furthermore, the early Gothic novel functioned as a machine for producing the thrills of horror and terror - black emotions that did not serve any perceivable social 
purpose. The literary circles held that literature was to cultivate the socially constructive emotions of empathy and sympathy in the reader. The enlightened, utilitarian frame of reference of the literary societies could not possibly accommodate the morally ambivalent, conflict-ridden Gothic novel, with its morbid fixation on a dark past which had supposedly been left behind.

When Dutch society became increasingly polarized along the lines of religious denominations in the course of the nineteenth century, Protestants and Catholics organized their own literary circuits, promoting appropriate reading materials and modes of writing (Mathijsen, 2004). In fact, one could even argue that the production and consumption of poetry and prose was one of the first social spheres to become 'pillarized'. Neither Catholics nor Protestants (nor Socialists, for that matter) were inclined to promote the Gothic mode. In fact, nothing could be further removed from their tastes. Entertaining stories were tolerated, but only if they taught useful moral lessons. Considering the fact that the literary societies exerted considerable impact on the production and reception of literature by organizing literary contests, handing out awards and providing a platform for discussing work in progress, we may safely conclude that this particular type of literary culture was hardly propitious to the flourishing of the Gothic novel on Dutch soil. ${ }^{5}$

\section{The socio-cultural revolution of the 1960s}

Having put forward a tentative explanation for the marginality of the Gothic novel in Dutch letters, we are now faced with the task of accounting for the equally remarkable entrance of the Gothic mode into post-World War II literature. ${ }^{6}$ We would like to defend the thesis that the Netherlands only experienced revolutionary infra- and superstructural modernization in the late 1950s and 60s. Due to the ravages that German occupation had inflicted upon large parts of the countryside, and the loss of the colony of Indonesia, rapid, intense and centrally controlled industrialization was necessary in order to keep poverty at bay. Within a decade or so, Dutch society developed into a fully fledged affluent society, including the concomitant consumerist mentality and hedonistic ethos (Righart, 1995; Kennedy, 1995).

Contrary to earlier modern interventions, infrastructural modernization now went hand in hand with radical transformations of religion, arts and sciences, and the culture at large. The optimism of post-war reconstruction paved the way for science-based experts such as psychotherapists, psychiatrists and family counsellors. These secular authorities took over the spheres of influence of priests and ministers, and this had a strong impact on Dutch family life. Child-rearing used to involve the moral duty to transmit crucial values to the next generation, such as obedience, prudence, thrift, cleanliness and so on. In the post-war period the so-called Utrecht School in the social sciences, a phenomenologically oriented group of educational theorists, psychiatrists and criminologists, functioned as a bridge between the old religious and moral values and the new scientific regime. They made a vital contribution to re-installing the family as the cornerstone of society in the aftermath of the war, propagating the image of the house as a safe haven, where children were allowed to be children and where all family members could develop their own individuality and satisfy their personal needs and desires. During the 
next decades child-rearing practices were shaped by the fun morality prevalent in affluent societies, which hinges on the imperative to enjoy. Family life now suddenly had to be fun, rather than a matter of duty and obligation. It was supposed to cater to the need for the personal fulfilment of both parents and children alike. Mothers were supposed to fulfil their own needs in meeting the needs of their children and possible conflicts of interest were smoothed over in the (widely translated) popular international child-rearing manuals produced by authors such as Benjamin Spock and Penelope Leach. The aim of child-rearing shifted from the moral aim of breeding productive citizens to the psychological aim of preventing emotional disturbances.

This moment in time was a period of brief but intense secularization and individualization, which was inaugurated by the dismantling of the pillarization system. Both Catholic and Protestant churches suffered a dramatic drop in membership and lost their grip on both the public and the private sphere. The affluent, consumerist and supposedly malleable society of the 1960s provided a fertile breeding ground for a whole spate of emancipation movements. With the help of government-financed scholarships, the working classes gained access to higher education. Youth groups managed to construct a world of their own through their highly vocal subcultures. Women's liberation, the sexual revolution, the gay and lesbian movements, and the burgeoning ideology of multiculturalism all seemed to reach their emancipatory targets within a mere two decades, perpetuating the tradition of at least two centuries of Dutch moderation, tolerance and non-violent social change. The overall image of the modernization of Dutch post-war culture is that of a 'velvet revolution'. Rather than setting the scene for fierce polarization between religious vocations and secular professions, feminists and conservatives, homosexuals and heterosexuals, lower and higher social classes, immigrants and natives, mono-culturalists and multiculturalists, consensus was quickly established on all major social issues - or so it seemed. Fervent religious convictions were dissolved in the indefinable blend of 'ietsisme', ${ }^{7}$ women's emancipation was quickly considered to be a matter of course, gay sex was soon declared to be perfectly legitimate between consenting adults, while multiculturalism became the dominant perspective on multi-ethnic postwar society. Apparently Dutch post-war culture was unable or unwilling to sustain a polemical debate between fully fledged opposing views and parties, as opposed to a country such as the United States, where systematic polarization between conservatives and liberals has been kept up for decades. Public debate in the Netherlands, on the other hand, is characterized by brief periods of disorientation that are quickly abrogated by a collective changeover to politically correct perspectives, up to the point of stifling dissenting views.

The abrupt transition from a religious, collectivist, traditionalist society to a progressive, secular, tolerant and pluralist world was coupled to strong feelings of moral and political superiority. The people of the Netherlands believed they excelled in civic virtue, and regarded themselves as a 'gidsland' (a guiding nation) that was to set an example for the rest of the modern world where non-violent solutions to problems of inequality were concerned (Kennedy, 1995). This image of the Netherlands as a paradise of tolerance and libertine laissez-faire evolved into a widespread stereotype, as is well illustrated by the following American appraisal of the documentary Sex, Drugs and Democracy (1994) by Jonathan Blank: 
Here's all the proof that you will ever need that Holland is the best country in the world! Despite that it is one of the most highly populated countries in the world in terms of space, they have the lowest crime rates, the lowest poverty rates, the lowest rates for abortion, teen pregnancy, AIDS, and other sex-related problems, and they are among the lowest in drug abuse ratings, despite the fact that hashish is sold openly in 'coffeeshops', and methadone and clean needles are available to anyone who asks. AND, they're among the highest in education, women's rights, acceptance of minorities, gay rights ... clean environment (one-fifth of Greenpeace's world membership is from Holland), heavy taxation of the rich(!), socialized health care, legal acceptance of euthanasia and abortion, and other cool things like nude beaches ... hardcore sex on TV, legal prostitution including brothels for the handicapped, and female priests and cantors. In fact, the only thing that Holland is committed to being against is child porn, intolerance, and all acts of violence ... It's nice to see that utopia exists somewhere! Or at least something as close to utopia as we'll ever find on this planet. (Cited in Kennedy, 2006: 115-18)

The Gothic novel only acquired cultural significance in this post-war climate of industrialization, progressivism, scientism, consumerism and the smothering of political conflict in an all-pervasive consensus culture. First, it criticized the reconstruction optimism and scientism of the 1950s, as in the Gothic narratives by Willem Frederik Hermans and Hella Haasse. In the wake of the socio-cultural revolution of the 1960s, postmodern and postcolonial varieties of the Gothic empowered authors to express doubts concerning the supposed progressivism and moral superiority of the Netherlands, deconstructing the cliché image of a liberal utopia. The style of this body of fiction tends to be hyperbolic, excessive and exuberant, frequently concocting camp combinations of pathos and bathos, holiness and banality, the comical and the tragic, religion and sexuality. As such, Dutch Gothic forms a stark contrast with the autobiographically oriented, anecdotic 'rainy realism' that was quite a trend in the 1970s, and may be exemplified by Maarten 't Hart's Een vlucht regenwulpen (A Flight of Curlews, 1978) or Jan Wolkers' Terug naar Oegstgeest (Back to Oegstgeest, 1965). The narrators in these novels look back on their youth before the 1960s in pillarized Holland with its various religious subcultures. These works often excel in minute descriptions of the Dutch landscape, are strongly introspective in nature, and tend to work towards some sort of resolution or reconciliation. The narrator in such novels finally manages to shrug off the stranglehold of religion, he finally forgives his dominant father, etc. Dutch Gothic novels refrain from this type of closure. They remain disorienting forces up to the end, eliciting a complex emotional response in the reader that consists of disavowal and identification, shock and laughter. Instead of the patient rendering of introspective and atmospheric minutiae, these novels have a grotesque way of blowing things out of all proportion. If religion comes into the picture, it is never as an autobiographical episode in the life of the main character that needs to be closed off, but as a haunting signifying force that colours the perception and interpretation of the events narrated.

Dutch Gothic moves within the parameters of the subgenre Fred Botting has branded as 'homely Gothic'. This constituted a major source of inspiration for Sigmund Freud's concept of 'the uncanny' (das Unheimliche). In homely Gothic, 'the bourgeois family is the scene of ghostly return, where guilty secrets of past transgression and uncertain class origins are the sources of anxiety' (Botting, 1995: 74; cf. Ellis, 1989). The setting of this type of Gothic is the family home, rather than abbeys, castles or wild romantic 
landscapes, the grand gloom of eighteenth-century Gothic giving way to horror within the home. This locale is turned into an overdetermined, polysemous signifier through a Gothic 'poetics of space' (Bachelard, 1958). The diverse parts of the house, upstairs and downstairs, cellar and attic, front and back, windows and shutters, are all imbued with a rich array of connotations that refer to different aspects of the human psyche. The literary machinery of homely Gothic, including recurrent motifs such as the haunted house, the hidden room, the indecipherable manuscript and the double, is operated by post-war novelists in order to stage the return of those aspects of culture that have supposedly become outdated (religion) or taboo (class distinctions, domestic violence, homophobia, sexism and racism). Dutch Gothic fiction unfolds an alternative view on the emancipation processes sketched above. Contrary to the dominant image of a velvet revolution, it dwells at length on the suppressed, conflict-ridden dimensions of modern post-war culture, as we will now point out below, in what can only be a summary discussion of some representative primary works.

\section{Social climbing}

Class has been generally supposed to be a non-issue in post-war Dutch society in view of its fairly inclusive, easily accessible system of higher education. Nevertheless, Thomas Rosenboom's Vriend van verdienste (Friend of Honour, 1985), a novel that is set in the 1960 s, represents a social dynamic that pivots around class distinctions. ${ }^{8}$ It deals with a friendship between four adolescent boys, two upper-class (Pieter and Otto) and two lower-class (Theo and Freddie). The well-bred brothers Pieter and Otto van Hal are fabulously rich and live in a stately home. Theo is keenly aware of this difference in class, and feels that he has to 'earn' the friendship of the two upper-class boys by doing them favours. This social inequality is the motor behind an escalating series of events that finally culminate in manslaughter. Tension mounts throughout the narrative, generating an intensely sinister, ominous and suffocating atmosphere.

Soon enough, Theo's favours acquire a criminal dimension as they come to include stealing goods at the behest of Pieter and Otto, which sets the police on Theo's tracks. Understandably, he seeks refuge in the spacious family home of the Van Hal brothers, who hide him away in a small room up in the attic. From that moment onwards, things begin to go awry. The four boys turn into each other's hostages, Theo wilfully submitting to his fate, while the brothers attempt to resist theirs. Now that they have lost their power over Theo's comings and goings, the Van Hal brothers all of a sudden feel a strong need to reassert their superior social status in an increasingly sadistic manner. They neglect Theo's physical needs, with the consequence that he has to do without water, food and toilet facilities for days at a stretch in the suffocating heat of August. Eventually, he feels compelled to drink out of his own toilet bucket, becoming more and more delirious as he aspires towards an almost mystical form of religious transcendence. He grows increasingly obsessed with converting the impure (the abject) into the pure (the subject). When he is reduced to drinking his own urine, he transforms this demeaning act into a religious rite. Theo believes drinking this 'water' will transubstantiate it into a purifying substance, just as Christians believe that the consumption of the blood and flesh of Christ during the ritual of the Eucharist will cleanse their sins. Thus his upward social 
aspirations are sublimated into the idiom of religious transcendence. Considering his elevated position way up in the Van Hal home, it seems as if he is on the brink of some sort of epiphany or apotheosis.

The expected climax reverts into its opposite when the Van Hal brothers smuggle him out of the house on a false pretext, whereby Freddie is supposed to kill him (another favour which this lower-middle-class boy has to deliver to his upper-class friends). However, because Theo is wearing one of Pieter's shirts, confusion ensues. The highly disturbed mother of the Van Hal brothers suddenly emerges from the nether part of the house like some sort of destructive, chtonic goddess, turning into the unwitting instrument of her own son's death. She mistakes Theo for her own flesh and blood, calling out Pieter's name, which enables Theo to escape. Likewise, but in reverse fashion, Freddie mistakes Pieter for Theo, and ends up killing the wrong person. By that time, what started as adolescent mischief has escalated into physical and psychological torture and even murder. Obviously, class distinctions are far from obsolete in this novel. On the contrary, transgressions of apparently minor class boundaries unleash extremely destructive forces of an almost metaphysical nature, considering the play with doubles and the religious idiom in which Theo's upward mobility is formulated.

\section{Women's liberation}

It is a familiar standpoint in the Netherlands that the Second Feminist Wave completed women's emancipation, removing all barriers to full social participation and economic independence for women. Gothic novelists, most notably Renate Dorrestein, seem to be of a different persuasion, suggesting that the hurdle of motherhood is still insurmountable. Dorrestein's hyperbolic representations of evil, even murderous, mothers subvert the science-based approaches to child-rearing that became normative in the secularized postwar period, enhancing the Dutch cult of domesticity with its predilection for the stay-athome mother. Child-rearing experts such as Spock and Leach may well propagate a picture of family life as a rationally controllable endeavour that can be highly fulfilling as well as a lot of fun, but this is not the picture that emerges from Dorrestein's fiction. The mothers in these novels are overruled by the archaic passions of sexual desire, jealousy and a thirst for revenge.

The ambivalence of the Gothic house as refuge and prison, haven and hell, is a leitmotif in Dorrestein's work, most notably in Unnatural Mothers (1992) and A Heart of Stone (1998). ${ }^{9}$ The last work has been cast in the shape of a frame story, opening with the return of a young woman, Ellen van Bemmel, to her old family home, where she is tied to her bed by an impending miscarriage. She passes the time flipping through her family photographs, which activate a whole spate of memories. Ellen's acts of recall reconstruct the dramatic history of the Van Bemmel family, which started out as a loving, warm and easy-going clan - in short, the ideal family. The Van Bemmel villa epitomizes this idyll. Its ample and commodious rooms envelop the centre of the house, the basement kitchen. Dwelling there felt like being sheltered within the belly of a large benevolent animal, according to Ellen's memories. It seems as if the four Van Bemmel siblings were never really driven out of their mother's womb. The family home is situated at the remote end of a dead-end street, with little or no interference from the outside world. The house is 
like a completely self-contained world, all the more so because the parents do not need to go out to work, as they run a small newspaper-clipping business on their own premises.

Nevertheless, this dream house is transmogrified into the site of a terrible tragedy after the birth of the fifth child, Ida. Once Ida has made her entrance into the Van Bemmel family, their mother changes from a tolerant and loving parent into a fiercely revengeful Medea. Ida appears to be a cuckoo that expels all the other siblings from the Van Bemmel love nest. Her mother is increasingly prone to religious delusions that are probably generated by her inability to reconcile her passionate sexual nature with her motherhood. These guilt feelings are projected onto the fruits of her sexuality. She feels her family is contaminated, which compels her to commit some act of expiation. Initially it looks as if only the latest child Ida has to be sacrificed. Her mother bathes her in searing hot water, presses an apple-corer into her infant pudenda and finally raises her knife in order to butcher her on the kitchen table. Then it suddenly strikes her that merely sacrificing the baby will not be enough. The whole family needs to die. The father of the Van Bemmel household does not intervene in this maddening symbiosis between mother and daughter, withdrawing into the ever expanding archives of his newspaper-clippings agency. He dutifully swallows the pills his wife doles out to her husband and children. Only Ellen accidentally survives because she happened to be out walking the dog at this fateful moment. The novel is open-ended. It remains to be seen whether Ellen and the child that is about to be born will manage to survive the strictures of motherhood.

A Heart of Stone suggests that a happy and undisturbed family home requires insulation from the threats and perturbations of the outside world. However, this very insulation eventually proves to be the undoing of the family. The dangers that are supposed to be outside the house are reproduced inside, undermining the family from within. Thus a happy family life necessarily remains a chimera, no matter which way you turn.

Unnatural Mothers also paints a pitch-black picture of mother-daughter relationships that is both grim and comical at the same time. Mothers and daughters form a continuous threat to each other's autonomy and agency here, up to the point when they prove incapable of inhabiting the same living space. They all live worlds apart from each other. On the rare occasions they are together, the subjectivity of at least one of them is irrevocably abrogated.

The characters in Unnatural Mothers can be divided into two categories. Some characters have got stuck, others move about freely. The first are more or less locked up in some home or other, the second fly around the world, always fleeing from the danger of getting stuck as well. The only way for women to remain mobile is by staying as far away from mother-daughter relationships as they possibly can. The plot of Unnatural Mothers revolves around the contrast between the siblings Bonnie and Meijken. They seem to be each other's opposites. Bonnie is an ambitious, successful scientist who travels around the world, having left her daughter Maryemma in the care of her ex-husband, who neglects the child. Her sister Meijken, on the contrary, does not go anywhere, being trapped in the back room of her husband's pharmacy. Not that she has been locked up by him. Rather, she has become the prisoner of her own body, being too heavy to leave the house or even to get out of her chair, hiding a family secret in the shady back room under thick layers of fat. We gradually find out that the imprisoned Meijken is a victim of her mother, who forced her to give up her illicit daughter Bonnie by pretending that Bonnie 
was her sister, meanwhile treating Meijken with scathing contempt for her stupid mistake of getting pregnant. The whole situation is brought to a crisis when Maryemma and her father, who live in Africa, come over for a Christmas visit. The fat, perennially pregnant, Meijken finally wriggles her way out of the back part of the house in order to pay her mother a visit in her nursing home, driven by an indefinable hodgepodge of emotions - that is, a need to finally receive maternal affection on the one hand, and the urge to retaliate against her mother for having robbed her of her child on the other. Once having arrived at her mother's nursing home, she manages to satisfy both desires in one go. Meijken sits herself down on her mother's lap like a child, crushing the fragile old woman under her weight in a liberating apotheosis of a mother-daughter symbiosis that is indeed breathtaking in the fullest possible sense of the word.

As in A Heart of Stone, the question is whether the fate of the younger generations, represented by Maryemma in this case, will be any better. It seems very unlikely, judging from the poetics of space in this novel. Significantly, Unnatural Mothers teems with mirror effects (mise-en-abyme). Thus Meijken's husband builds a doll's house for their niece Maryemma as a Christmas present. The miniature house is meant to exude warmth and cosiness: it can be illuminated by tiny bulbs on the inside, and it even has windows that can be opened and shut. However, it does not appear at all cosy to Meijken, who recognizes her own imprisonment in the suffocating neatness of the tiny doll's house, which also bears a close resemblance to the holiday resort house rented by Maryemma and her father for the Christmas holiday. Such resemblances are ill omens indeed. But the most ominous event of all is Maryemma's sacrifice of her imaginary playmate, Victor Hugo. This fantasy creature is the receptacle of all the care and attention that Maryemma has to do without, being a neglected child. In an effort to bond with her nonchalant, noncommittal father, she sacrifices Victor Hugo to her father, sending him into outer space forever. This is a highly revealing gesture, considering the symbolic contrast between mobile and immobile characters in this novel. It seems as if Maryemma confers her own freedom and subjectivity on Victor Hugo, in order to take leave of these precious goods forever. His flight painfully contrasts with Maryemma's loss of wings, as she feels compelled to let go of her own autonomy and agency in exchange for a meagre supply of parental care and attention. Sure enough, her mother Bonnie managed to retain her own subjectivity by simply abandoning her child, but this is only achieved at the expense of her daughter's opportunities to assert herself.

While the science-based child-rearing advice industry suggests that the aspirations of mothers and daughters can be easily harmonized, with mothers finding all the fulfilment they need in taking care of their offspring, Dorrestein's fiction represents a universe in which the desires of the mothers are always fatal to their daughters, while the daughters can only retain their subjectivity by keeping their mothers at bay. Modern experts have been extremely busy advising Dutch women how to balance their careers and families through delicate piecemeal engineering. Dorrestein, however, foregrounds the futility of each and every balancing act by depicting agency and motherhood as permanently warring forces. Consequently, motherhood maims all women who somehow become caught up in it, because they have to sacrifice either their subjectivity or their child. Both options make it downright impossible to escape from motherhood unscathed - another irresolvable Dorrestein dilemma. 


\section{Gay emancipation}

It has become an established dogma in Dutch society that homosexuality is a perfectly normal sexual inclination, and that it is therefore unacceptable to exclude homosexuals from social institutions, including marriage and the right to adopt children. The Netherlands prides itself on being one of the first Western countries in which homosexuals enjoyed exactly the same rights and obligations as heterosexual couples. Authors such as Gerard Reve and Jan Wolkers have been credited with paving the way for the onset of the (sexually) permissive society, as their novels were among the first literary works to include lengthy, detailed and graphic sex scenes of a hetero- and homosexual nature. Remarkably enough, however, self-confessed homosexual authors such as Gerard Reve and Frans Kellendonk had a way of going against the grain of the politically correct communis opinio by depicting homosexuality as a fearsome sickness or perversion. This perspective on homosexuality is imbued with religious connotations in their work, which is another anomaly in the secular, enlightened, liberal climate of the post-war period.

Gerard Reve's Gothic thriller De vierde man (The Fourth Man) is rife with Gothic paraphernalia, such as the setting of the remote, storm-tossed house, ambiguous sources that cannot give truly reliable information (overheard phone calls, stolen letters, found keys that give access to other, equally unreliable sources), the femme fatale and the unreliable narrator. De vierde man features a gay man in the leading role, Gerard, who enters into a sexual relationship with a 'Sadeian woman', Christine, but only as a means of getting in touch with Christine's lover Herman. Gerard envisages this ménage à trois in religious, or perhaps one should say blasphemous, terms, comparing the lascivious Christine to the Virgin Mary, who may grant Gerard access to Herman/Jesus: 'Through her, to him'. This curious combination of Catholicism and homoeroticism is typical of Reve, who flaunted not only his homosexuality but also his lifelong devotion to the Mother Church. More than that, he persistently drew upon a religious vocabulary to render detailed descriptions of homosexual sadism, concocting a new stylistic register that has gone down in literary history as 'Revism'. ${ }^{10}$

Frans Kellendonk's novel Mystiek Lichaam (Mystic Body, 1986) dishes out a comparable cocktail of homoeroticism and religious mysticism, although the ingredients are mixed somewhat differently here. Mystiek Lichaam narrates the related, but opposite, lives of a brother and sister, Magda and Leendert. Magda wants to embed herself in her family, within tradition and community, by giving birth to a child, thereby perpetuating a 'dynasty of life'. Leendert, on the other hand, does not want to have anything to do with procreation and cultivates an entirely different set of values, glorifying homosexuality, biological transcendence (he compares homosexuality to 'sexual space travel') and artificiality (Leendert is an art dealer). He is keen on breaking all ties with the past, but he has to admit in the end that he has perpetuated a dynasty as well, albeit a dynasty of death rather than life (it turns out that Leendert has AIDS). ${ }^{11}$ The book caused a scandal when it was published, with the author being accused of anti-Semitism, self-hatred and retrograde religiosity.

The Gothic features of Mystiek Lichaam become apparent when we compare the novel to a classic within the genre, Edgar Allan Poe's The Fall of the House of Usher (1839). ${ }^{12}$ Poe's short story also features a pair of siblings in the leading role, twins 
moreover, who are both sterile in the metaphorical sense of the word - that is, incapable of turning outwards and loving others who are indeed 'other', turning to each other in a narcissistic, incestuous obsession with their own mirror image. They can neither live with, nor without each other, with the brother first burying his sister alive and the resurrected sister subsequently falling on top of her brother as they both die. Inevitably, the hoary, aristocratic Usher family collapses or rather implodes, because of the incapacity of the last two siblings to perpetuate the family line, likewise installing a dynasty of death rather than life.

Thus, Reve and Kellendonk loosely associate homosexuality with blasphemy, sadism, sterility, narcissism, criminality and degeneration, resuscitating all the discriminatory stereotypes of homosexuals as some sort of homeopathic cure for homophobia. Certainly, they do not appear to be particularly eager to bond with modern, enlightened advocates of gay liberation and coming out, preferring to devote close attention to the skeleton in the closet instead.

\section{Multiculturalism}

During the closing decades of the twentieth century, multiculturalism was the only officially condoned political response to the challenges of immigration and globalization in the Netherlands. It was felt that new citizens from former colonies in the Caribbean and Indonesia, as well as migrant labourers from Turkey and Morocco, were best left to their own devices, in order to give them the opportunity to cultivate their native customs, religions and languages. Cultural differences were to be tacitly accepted, rather than openly questioned or challenged. There was little pressure on immigrants to assimilate Dutch culture or integrate into Dutch society, with the result that these groups occupied their own special sectors within major Dutch cities, where they spoke their own language, ran their own shops, instituted their own schools, worshipped in their own mosques, and so on. In fact, the Dutch way of handling ethnic diversity bore a close resemblance to the good old system of pillarization. One of the unanticipated results of multicultural laissez-faire was that second- and third-generation immigrant children experienced severe difficulties at school, often dropping out prematurely without a diploma, which debarred them from access to the better-paid jobs in the Netherlands.

Predictably, multicultural tolerance has also come under attack in Dutch Gothic, for instance in the novel Wolfstonen (Wolftones, 2003) by Herman Franke. Again, the setting is a house and this time we are dealing with a postmodern apartment building, designed by a young, enthusiastic architect, who has indulged in playful features such as rounded corners, a transparent staircase surrounded by huge plates of glass, and bedrooms with raised platforms as 'seats of love'. This monument of postmodern playfulness and romantic reverie is erected in a multicultural working-class area, in order to fill a hole in a row of dilapidated nineteenth-century houses. For decades on end, this gaping hole fed the collective fantasy of the inhabitants of the area. Given the myriad urban myths about the crimes passionels that took place on this small plot of waste land, the new apartment building is predestined to become a haunted house.

The architectural Fremdkörper only attracts residents from the educated elite, such as a journalist, a translator, a civil engineer, an assistant professor and a musician. Most of 
them need to insulate themselves from their surroundings in order to be able to devote themselves fully to their intellectual occupations. Others isolate themselves because they are self-obsessed and hung up on traumatic episodes from their past. The epitome of insulation is embodied by the musician Elto, who constructs a soundproof studio within his apartment so as not to disturb or be disturbed by his fellow inhabitants. In addition to the studio, Elto uses various devices to dampen the sound of his violin, namely a mute and a device for killing the 'wolf tones' - non-musical, extraneous noises that happen to accompany the movement of the bow over the strings. All these devices function as icons for the way in which the cultured elite attempt to safeguard their own privileged niche in society by closing their eyes to the sordid reality of the outside world. Not unimportantly, this is the same elite that cherish the ideals of tolerance, liberalism and multiculturalism.

As it happens, the insulation strategies of the worried well fail miserably, because the apartment building turns out to be an acoustic hell that amplifies rather than smothers sounds from outside. The uncultured neighbours indulge in noisy sports and vicious gossip about the highly refined inhabitants of the apartment building, who function as some sort of substitute for the more benign urban myths that used to cling to this spot. The residents of the apartment building are utterly incapable of protecting themselves against the intrusive noises of their fellow human beings. Ironically, the newcomers become the cause of increasing solidarity among their poorer neighbours, a development they would have approved of were it not for the fact that this fraternization is achieved at their expense. White trash and immigrants band together, turning against the middleclass newcomers in unison, up to the point when social tensions can only be relieved by a violent climax. The people of the seedy neighbourhood conspire to humiliate a vulnerable old couple, to rape two female residents, and finally to set fire to the whole building. Significantly, Elto, of all people, the very incarnation of civilized refinement, dies in the flames. Again, class differences do not appear to be as irrelevant as they are commonly considered to be in the Netherlands. One has to admit that some form of ethnic integration did take place here, but only at the expense of the group who has the educational background to embrace multiculturalism as a theoretical ideal. More precisely, integration and assimilation are achieved under the pressure of mass hysteria. Apparently, ugly noises (the 'wolf tones' of the title) cannot be simply shut out. When you attempt to suppress them, they return with renewed force, a highly familiar message for anyone who is well versed in Gothic fiction. Those with the greatest aptitude for shutting out discord turn out to be most vulnerable to its vengeful return, as becomes manifest from the tragic fate of the beautiful, noble and highly gifted Elto. So much for progressivism, moral superiority and tolerance. So much for utopia.

\section{The myth of Dutch progressiveness}

In what ways could the case of the Dutch Gothic novel contribute to a comparative approach to Gothic studies? Evidently, Dutch authors did not play a significant role in the rise and early development of the Gothic novel. Our inquiries have not set us on the track of some hidden ancestor of or surreptitious influence on Anglo-Saxon and European Gothic fiction as it developed in the course of the eighteenth and nineteenth centuries. This state of affairs only changed during the latter half of the twentieth century, when 
Dutch literature came to fully participate in an overall international revival of the Gothic mode in both literature and culture at large. Some of the authors concerned seem to have arrived at the typical motifs and obsessions of the genre more or less spontaneously or unintentionally, such as Willem Frederik Hermans and Helga Ruebsamen, while others, such as Renate Dorrestein, Hella Haasse and Frans Kellendonk, obviously take their cue from English literature. In either case, the generic repertoire of the Gothic novel is finetuned towards the specifics of post-war Dutch culture. Dutch Gothic stages the tensions and contradictions between a national self-image and international stereotype on the one hand, and a taboo zone of persistent social inequality and intolerance on the other. The Gothic novel became a prominent cultural force in Dutch culture at a time when the Dutch nation was finally exposed to the wholesale revolutionary modernization of both the infrastructure of society and of the life world. Dutch novelists mobilized the literary machinery of homely Gothic in order to subvert the complacent Dutch (self-)image of a progressive, liberal, tolerant nation that smoothly accommodated the claims of the various emancipatory movements of the post-war period without much ado. While these movements were still in the process of gathering steam, they were already declared to be obsolete - that is, smothered underneath the blanket of Dutch consensus culture. In the meantime, there were not all that many factual achievements to substantiate the supposed 'completion' of women's emancipation, gay liberation or the integration of ethnic minorities into mainstream Dutch culture. Dutch women have been notoriously slow in conquering the job market, while immigrants were ghettoized in the poorer sections of the cities, where they proved to be unable to participate in Dutch society. Homosexuals do indeed enjoy equal rights, but that does not necessarily imply that the culture at large has purified itself of discriminatory stereotypes.

James Kennedy, an American expert on contemporary Dutch history, has aptly qualified the complacent Dutch (self-)image of the liberal and tolerant European nation par excellence as the 'myth of Dutch progressiveness' (2000). In the eyes of the international community, this myth was shattered by the political murders around the beginning of the twenty-first century, namely the assassination of the populist anti-Islamic politician Pim Fortuyn in 2002, and the murder of the highly provocative filmmaker Theo van Gogh in 2004. In a curious twist of fate, a right-wing politician was killed by a member of the radical left and an anarchistic left-wing filmmaker was killed by a fundamentalist Muslim, exploding the discourse of tolerance in a way that no one could any longer afford to ignore. However, Dutch Gothic novelists had already been busy staging the violent conflicts lurking underneath the smooth surface of consensus culture decades before these painful events shook the public sphere. They had developed their own unique view on Dutch modernity by exploiting the themes, motifs, symbols and narrative structures of the Gothic repertoire way before these political murders shocked the nation into an awareness of the fierceness of political conflict.

On a methodological level, we hope our case study has demonstrated two things. First, that the discrepancies and convergences between the ramifications of the Gothic mode in diverse national literatures are best explained with references to differences in the modernization processes that start at different moments and go through divergent stages in different parts of the world. Thus we have inferred the reasons for the belated entrance of the Gothic mode into Dutch literature and culture from the specifics of the 
modernization of the Netherlands. Second, our case also shows that the eventual importance of the genre to post-war literature is better not discussed primarily as a matter of 'influence', with Dutch authors suddenly becoming sensitive to examples from other national literatures that did cultivate the Gothic mode. Rather, we prefer to understand this phenomenon as a matter of a specific socio-cultural constellation, in which the modernization of the life sphere is forcefully propagated in a top-down manner, sweeping all sorts of pre-modern perspectives under the carpet, and thereby creating a cultural climate that is conducive to the flourishing of the Gothic mode.

Dutch homely Gothic vitally contributes to a Gothic poetics of space by exploiting the trope of the uncanny house in highly inventive ways. As we may infer from Gaston Bachelard's La Poétique de l'espace (1958), there is a certain cultural logic to this root metaphor, and therefore authors do not necessarily need clear-cut examples in order to put this trope to good use. This does not mean that literary innovations are determined by changes in society and culture, as these changes are deflected through the prism of specifically literary tropes and commonplaces. Dutch Gothic reveals quite clearly that literary works are indeed 'transvestisms of social conflicts'. ${ }^{13}$ Literary autonomy and social relevance have proved to be mutually enhancing, rather than conflicting qualities here.

\section{Notes}

1 Of course, Horner was not the first to open the field of Gothic studies to comparative perspectives. The books edited by David Punter (2000) and Jerrold Hogle (2002) also contain chapters on European Gothic. See also Cornwell (2000), Hale (2002), Davenport-Hines (1998) and Van Gorp (1998).

2 This becomes apparent from Schouten (1997). Evidently, this does not mean that no Gothic tales whatsoever were produced. Occasionally, the incidental horror story was indeed written, but mostly by 'student-authors' such as Nicolaas Beets, Johannes Kneppelhout and Johannes Hasebroek. By the time these authors had acquired a good literary reputation, however, they had distanced themselves from their early Romantic aberrations as the sins of their youth. For an anthology of these stories, see Bervoets (1983). Only some of the stories collected in this volume may count as Gothic tales, however, as horror stories and Gothic fiction are not entirely synonymous. See also Mathijsen (2004) for a lively discussion of these young Dutch Romantics. See also note 5.

3 For a more extensive study of these works, see Buikema and Wesseling (2006).

4 This term derives from the vocabulary of New Historicism, and was introduced by Tompkins (1986).

5 There is at least one significant exception here, namely the Rederijkerskamer voor Uiterlijke Welsprekendheid (The Chamber of Rhetoric for the Cultivation of Eloquence), a club of students from Leiden University that was active in the 1830 s and counted the authors mentioned in note 2 among their members. These young authors explicitly took leading French and German Romantic authors as their models, occasionally producing a tale with a Gothic flavour to it. See also Zonneveld (1993). However, this particular society was generally felt to be a highly controversial exception, which, moreover, was fairly short-lived. Most of its members had turned to the production of devotional prose and poetry by the time they had reached maturity, looking back on their youthful literary production with embarrassment and shame. 
6 Again, we do not want to go so far as to state that Dutch authors did not produce any Gothic novels earlier in the twentieth century. In our monograph Het heilige huis (2006) we have discussed the novels De stille kracht (The Hidden Force, 1900) and Van oude mensen, de dingen die voorbij gaan (Old People and the Things that Pass, 1906) by the internationally oriented writer Louis Couperus as eminent examples of '(post)colonial Gothic'. Undoubtedly, once the concept of the Gothic novel has caught on in the criticism of Dutch literature, various other Gothic novels will be discovered. But there is a significant difference between the isolated individual who produces an incidental Gothic work and a trend.

7 Literally translated, this term means 'somethingism', a term which refers to the fact that the great majority of people nowadays no longer believe in a personal God, but they do believe in a rather uncommitted manner in a 'Something' - a higher transcendent principle, or whatever.

8 For a much more detailed analysis of this novel from the perspective of the Gothic, see Andeweg (2005).

9 For translations of Dorrestein's work, see her homepage: www.renatedorrestein.nl. See also Buikema and Wesseling (2007).

10 One could also argue that Reve draws upon a very old, pre-modern stylistic register here, as mystics have traditionally used sexual imagery to express their experiences of religious ecstasy from the Middle Ages onwards. This becomes particularly apparent in the muchdiscussed 'donkey passage' in the autobiographical work Nader tot U (Closer to Thee, 1966), where Reve suggests that God will reincarnate himself as a donkey on the occasion of his second coming. Nobody will recognize him, except for Reve, who will go to bed with him immediately. However, Reve will take precautionary measures by wrapping bandages around his hoofs, so he will not be hurt when the donkey makes jerking movements when he comes. Understandably, many people were scandalized by the passage, and several members of parliament asked critical questions about it, which resulted in the author being brought to trial. The trial dragged on for two years, with Reve finally being acquitted of all charges of blasphemy, not least on account of a lengthy exposition by the author himself in which he explicated his image of God in studied detail.

11 Just like the author himself, who died of AIDS in 1990. He was one of the first publicly known victims of what was at that time a relatively unknown disease. See also Andeweg (2007).

12 In view of the fact that the author studied English language and literature and was active as a literary critic and translator for a while, it is more than likely that he knew Poe's work quite well.

13 The phrase derives from Mathijsen (2004).

\section{References}

Andeweg A (2005) Bij hoog en bij laag: Het gotieke in Thomas Rosenbooms Vriend van verdienste. Nederlandse letterkunde 10(1): 18-33.

Andeweg A (2007) The ghost in the closet: Frans Kellendonk and the Gothic. In: I van Elferen (ed.) Nostalgia or Perversion? Gothic Rewriting from the Eighteenth Century until the Present Day. Newcastle upon Tyne: Cambridge Scholars Publishing, 138-51.

Bachelard G (1958) La Poétique de l'espace. Paris: Arnoud.

Bervoets J (ed.) (1983) Nederlandse gruwelverhalen uit de negentiende eeuw. Amsterdam: Veen. Botting F (1995) Gothic. London: Methuen. 
Buikema R, Wesseling E (2006) Het heilige huis: De gotieke vertelling in de Nederlandse literatuur. Amsterdam: Amsterdam University Press.

Buikema R, Wesseling E (2007) Gothic engineerings in child rearing manuals and feminist novels: Spock meets Dorrestein. In: I van Elferen (ed.) Nostalgia or Perversion? Gothic Rewriting from the Eighteenth Century until the Present Day. Newcastle upon Tyne: Cambridge Scholars Publishing, 152-68.

Cornwell N (2000) European Gothic. In: D Punter (ed.) A Companion to the Gothic. Oxford: Blackwell, 27-39.

Couperus L (1900) De stille kracht. Ede: Veen.

Couperus L (1906) Van oude mensen, de dingen die voorbijgaan. Amsterdam: Veen.

Davenport-Hines R (1998) Gothic: 400 Years of Excess, Horror, Evil and Ruin. London: Fourth Estate.

De Vries M (2001) Beschaven! Letterkundige genootschappen in Nederland 1750-1900. Nijmegen: Vantilt.

Dorrestein R (1992) Ontaarde moeders. Amsterdam: Contact.

Dorrestein R (1998) Een hart van steen. Amsterdam: Contact.

Ellis K (1989) The Contested Castle: Gothic Novels and the Subversion of Domestic Ideology. Champaign: University of Illinois Press.

Franke H (2003) Wolfstonen. Amsterdam: Podium.

Haasse H (1950) De verborgen bron. Amsterdam: Querido.

Hale T (2002) French and German Gothic: the beginnings. In: JE Hogle, The Cambridge Companion to Gothic Fiction. Cambridge: Cambridge University Press, 63-85.

Hart M’t (1978) Een vlucht regenwulpen. Amsterdam: De Arbeiderspers.

Hermans WF (1953) Paranoia. Amsterdam: GA van Oorschot.

Hermans WF (1989) Au pair. Amsterdam: De Bezige Bij.

Hogle JE (2002) Introduction: the Gothic in western culture. The Cambridge Companion to Gothic Fiction. Cambridge: Cambridge University Press, 1-21.

Horner A(ed) (2002) European Gothic: A Spirited Exchange 1760-1960. Manchester: Manchester University Press.

Kellendonk F (1986) Mystiek Lichaam. Amsterdam: Meulenhof

Kennedy J (1995) Nieuw Babylon in Aanbouw: Nederland in de jaren zestig. Amsterdam: Boom.

Kennedy J (2000) The myth of Dutch progressiveness: the Netherlands as 'Guide Land'. The Low Countries 7: 220-4.

Kennedy J (2006) Nederland als het meest progressieve land ter wereld. In: W van Noort and $\mathrm{R}$ Wiche (eds) Nederland als voorbeeldige natie. Hilversum: Verloren, 105-18.

Mathijsen M (2004) Nederlandse literatuur in de Romantiek 1820-1880. Nijmegen: Vantilt.

Punter D (ed.) (2000) A Companion to the Gothic. Oxford: Blackwell,

Reve G (1966) Nader tot U. Amsterdam: Van Oorschot.

Reve G (1981) De vierde man. Amsterdam: Elsevier Manteau.

Righart H(1995) De eindeloze jaren zestig: De geschiedenis van een generatieconflict. Amsterdam:

De Arbeiderspers.

Rosenboom T (1985) Vriend van verdienste. Amsterdam: Querido

Ruebsamen H (1997) Het lied en de waarheid. Amsterdam: Contact.

Schouten D (1997) Duivelse boeken: Twee eeuwen griezelliteratuur in de Lage Landen: Een bibliografie. The Hague: Stichting Bibliographica Neerlandica. 
Singeling C (1991) Gezellige schrijvers: Aspecten van letterkundige genootschappelijkheid in Nederland, 1750-1800. Amsterdam: Rodopi.

Tompkins JP (1986) Sensational Designs: The Cultural Work of American Fiction, 1790-1860. New York: Oxford University Press.

Van der Woud A (2006) Een nieuwe wereld: Het ontstaan van het moderne Nederland. Amsterdam: Bert Bakker.

Van Gorp H (1998) De romantische griezelroman: Een merkwaardig randverschijnsel in de literatuur. Leuven: Garant.

Wolkers J (1965) Terug naar Oegstgeest. Amsterdam: Meulenhof.

Zonneveld P (1993) De romantische club: Leidse student-auteurs 1830-1840. Leiden: Athenae Batavae.

Rosemarie Buikema is head of the Department of Media and Culture Studies and Chair of the Graduate Gender Programme at the Faculty of Humanities, Utrecht University, the Netherlands. She writes on representations of truth and reconciliation, the Gothic and the Grotesque, and literary biography.

Elisabeth Wesseling is affiliated as an associate professor to the Department of Literature and Art, Faculty of Arts and Social Sciences, Maastricht University, the Netherlands. She has published on the cultural construction of childhood in fiction (novels, movies, children's literature) and science (anthropology, developmental psychology). She has co-authored a monograph on the Dutch Gothic novel with Rosemarie Buikema. 